This is a self-archived version of an original article. This version may differ from the original in pagination and typographic details.

Author(s): Lehtonen, Jussi; Pöyhönen, Sari

Title: Documentary theatre as a platform for hope and social justice

Year: 2019

Version: Accepted version (Final draft)

Copyright: (c) Routledge, 2018.

Rights: In Copyright

Rights url: http://rightsstatements.org/page/InC/1.0/?language=en

Please cite the original version:

Lehtonen, J., \& Pöyhönen, S. (2019). Documentary theatre as a platform for hope and social justice. In E. Anttila, \& A. Suominen (Eds.), Critical Articulations of Hope from the Margins of Arts Education : International Perspectives and Practices (pp. 31-44). Routledge. https://doi.org/10.4324/9781351111195-3 


\section{Documentary theatre as a platform for hope and social justice}

Jussi Lehtonen \& Sari Pöyhönen

\section{Introduction}

The refugee crisis in 2015 brought a tipping point for Europe regarding asylum seekers and refugees from countries like Syria, Iraq, and Afghanistan. Finland received over 32,000 asylum seekers. Amongst them hundreds were artists, such as actors, musicians, poets, dancers, and circus artists. This convergence of asylum seekers and refugees resulted in heated media debates and polarized discussions about 'refugee flows' and 'leaking borders.' $M$ any artists and researchers took part in the public discussion by taking a firm stand against harsh asylum policies. This chapter will discuss one collaborative project, a documentary theatre project Other Home (in Finnish: Toinen koti), and the process in which a hybrid community of artistic expression was formed.

Jussi: I work as artistic designer, director, and actor in the National Theatre in Helsinki, Finland. I felt an urgent need to take part in the public discussion about the so-called 'refugee crisis' and integration policies in Finland. I was also interested in the role of Muslim faith in Finland. I started planning the Other Home documentary theatre project (Kiertuenäyttämö, 2018) winter 2016 and invited three artists to form a core team of the project: a play writer Kati Kaartinen, a composer Sanna Salmenkallio and an actor Terhi Panula. In Other Home we started from the following questions: What is integration? Who feels at home where, with whom and how? How can a professional artist with a refugee background find a place in a new country? Could it be that Home is where the Art is? Later on in the spring I invited researcher Sari to join the project. I had heard from my colleagues that Sari has been involved in collaborative projects dealing with issues of forced migration, and I was interested in including a research dimension in this artistic project.

Sari: I work as professor of applied language studies in the University of Jyväskylä, Finland. I have been doing collaborative linguistic ethnography about everyday life of asylum seekers in a reception centre and struggles they faced in their asylum process (Pöyhönen, Tarnanen $\&$ Simpson, 2018). I have also worked in areas of migration and integration policies (Pöyhönen \& Tarnanen, 2015), and this is why I found the Other Home project very significant, because it enabled refugees and asylum seekers to bring their own view to the stage. I was especially interested in questions of belonging and non-belonging, and how the hybrid community of artistic expression would be constructed using various linguistic and 
other semiotic repertoires. In this project, we collaborated with Jussi to combine our expertise and knowledge of doing art, artistic research, and linguistic ethnography in a migration context. By linguistic ethnography I mean studying the local and immediate interactions of participants from their perspectives and consider how these interactions are embedded in wider cultural contexts and social structures (Copland $\&$ Creese, 2015), such as asylum policy.

In this chapter we, Jussi and Sari, examine how people from different backgrounds, experiences, cultures, and art forms come together and create a hybrid community of artistic expression in a documentary theatre project Other Home. We will focus on the journey of one member of the community, an Iraqi actor Bakr Hasan, who was seeking asylum in Finland when we first met him in Spring 2016. In this chapter, we describe how Bakr navigates the labyrinth of the Finnish asylum system, and faces problems in convincing the Finnish Immigration Service (M igri) that he is a professional actor under the threat of being persecuted. We explore, how being a member of the Other Home community helps him in his difficult situation, supports his career as an artist, and offers a space for belonging. We also pay attention to our emerging roles as activists, and what this brought into our understanding of crossing professional borders (see Sachs, 2000) and taking other person's position. During the project we also followed the process of social and emancipatory consciousness, in Paolo Freire's (1974/2013) words conscientizaçao, which "represents the development of the awakening of critical awareness" (p. 15). Conscientizaçao is a non-linear and dialectical process to become an author and social actor of person's own destiny. This process cannot evolve in a vacuum; a person cannot liberate herself alone, but needs other people (Darder, 2015).

\section{Creating a hybrid community of artistic expression in a documentary theatre project}

A development called social turn has been discussed in the field of performing arts during the past few decades. M any artists and art institutions have started to consider how to widen their concept of audience, citizenship, and artisthood beyond the traditional boundaries (Jackson, 2011). The Finnish National Theatre was founded in 1872. For nearly 150 years its task has been to put on stage Finnish and international classics and contemporary plays in Finnish. In 2010, the theatre decided to open a new department called Kiertuenäyttämö - Touring Stage. Its idea is to take productions to locations which have little or no access to live performances: health care and social institutions, prisons and reception centres for asylum seekers. This initiative also develops projects through 
interaction with different kinds of marginalized groups, with the focus on creating socially inclusive documentary theatre (Touring Stage, 2018).

Jussi: Over the past few years, as a part of my work as the artistic designer of The Touring Stage and post-doctoral research within the ArtsEqual research project, I have been developing the idea of a hybrid community of artistic expression. In principle, this ephemeral community is formed by and includes people from different backgrounds who collectively embark upon creating a joint piece of art, most often a performance with documentary traits. With hybridity I mean making the effort of bringing together people who otherwise would not be in contact with each other, and being open to their stories, situations and conceptions of art (see Bhabha, 1994).

Sari: The notion of a hybrid community of artistic expression is closely connected with belonging. Belonging is a complex process and a sense of feeling especially for people who are displaced (Anthias, 2012). Individuals simultaneously belong "there" by maintaining relationships with those who remained and memories of the places from which they have been dislocated, and belonging to "here" within their current places and relationships (Butler \& Spivak, 2007). Non-belonging, conversely, refers to processes and feelings of exclusion from a community, relationships and places. I have noticed all these dimensions of belonging and non-belonging when doing research with asylum seekers, who are trying to resettle in a new country while keeping in touch with the loved ones. Feelings of nonbelonging emerge for example when their asylum claim has been denied, or when they have experienced racialized practices in their daily life.

While the hybrid community of artistic expression defines its working methods and artistic goals jointly, its members share certain general ideas. The community aims to call attention to the stories of marginalized and/or stigmatized people; it also seeks to provide the members an opportunity to participate in the public discourse through the medium of art. The very basic element of the hybrid community of artistic expression is learning to comprehend each other's positionality. This occurs through the communal process of rehearsing and performing a work of art. Putting oneself in the other's position also takes place between the performers and the members of the audience who temporarily become a part of the community when the performance is being played. It also happens on a basic human level when people learn to know each other and imagine each other's conditions of life. 
Forming a hybrid community of artistic expression can be seen as a method of making a documentary theatre performance with a special emphasis on the notion of community. It illuminates the situations of differently marginalized people and makes them more understandable and visible to others within the broader society. In this way putting oneself in the other's position is also an act of civic awareness. It's a kind of an artistic and social experiment of living with the politics of difference (Hall, 1987).

\begin{abstract}
Jussi: The National Theatre is a large, publicly funded art institution that can act as a means to integrate people from different spheres of society within its core artistic practice and social influence. Persons involved in these temporary communities are often people who otherwise might have not found their ways to the theatre. For example, for the project Fear of freedom, I invited people with prison background to partake in this kind of artistic community with the National Theatre resident artists. In this project the ephemeral community turned to be permanent, when its members decided to start their own theatre group, Porttiteatteri - The Gate Theatre, once the project had ended. It still works in Helsinki offering a possibility for people with prison background to make theatre and make their voices heard (Lehtonen, 2016; Porttiteatteri, 2018).
\end{abstract}

The Other Home is another example of this kind of project formulated around the central idea of a hybrid community of artistic expression. It involved participants from three roughly defined groups of people: 1) professional refugee artists; 2) professional Finnish artists working in the Finnish National Theatre; and 3) amateurs who had participated in a theatre workshop open for refugees and who at this time wanted to join the performance as members of the chorus.

The community chose to utilize documentary theatre as it is a potent way of exposing inequalities in society and practicing socially engaged art. Documentary theatre (also sometimes referred to as docudrama, ethnodrama, verbatim theatre, theatre of witness, or theatre of fact) is a problematic concept the meaning of which can refer either to the content or the form of a performance. Jules Odendahl-James (2017) describes it as a performance built from collected materials such as trial transcripts, written or recorded interviews, newspaper reporting, visual images, or video footage, government documents, biographies, and scientific research. It can be political, social, or personal. It can be done by professional performers or amateurs.

Jussi: In my field the term documentary means bringing marginalized people as performers in a professional theatre production and giving them a chance to talk for themselves in different ways. I would describe the final product of the Other Home as documentary 
theatre as it told the stories of the individuals involved in the process using their interviews, juridical documents and speeches of politicians as materials for the manuscript. The most concrete example of a documentary performance was highlighted in the physical existance of refugee artists on stage: their bodies, breathing, voices and movement. It also illuminated the story of a community, and particularly an imagined story of the community it considered itself to be (Anderson, 1991). In the Other Home project a very crucial moment took place when the hybrid community of artistic expression encountered its spectators who temporarily gave their unique input in its already existing hybridity. It was a community looking at a community asking itself what this new community actually is (Koski, 2015).

\section{Becoming a member of a hybrid community of artistic expression}

In the Spring and Autumn 2016, the team interviewed 15 refugee artists - musicians, singers, rapartists, actors, and poets who had fled from Iraq, Iran, and Syria. The refugee artists were recruited through various sites, such as Helsinki City Information Center on Immigration Issues, job office, reception centres for asylum seekers, artist networks, educational institutions, and nongovernmental organizations promoting arts and culture. One interview session lasted approximately between one and two hours. The aim of these initial sessions was to investigate prior background information such as the artists' lives in their countries of origin, reasons they fled from war zones and areas of conflict and further, how they are continuing or they continue their lives in Finland, and were they able to practice their art in the new environment. There was another purpose for the interviews. The team looked for individuals who would volunteer to join the project later as performers. All the four main characters, of what was later to be called the Other Home performance, were people with refugee background found through these interview sessions.

We use the term refugee in order to acknowledge personal accounts of the artists. The word refugee was widely used by the participants when talking about their situations and experiences - even though many of the artists were still in the process of seeking asylum in Finland. According to Amnesty International (2009) a refugee is "a person who has fled their country of origin and is unable or unwilling to return because of a well-founded fear of being persecuted because of their race, religion, nationality, membership of a particular social group or political opinion". United Nations High Commissioner for Refugees (UNHCR, 2006) notes that all refugees have initially been asylum seekers. The topic of professional artists fleeing their home country or countries of residence because of the threat of being persecuted was central to the project and this theme 
became linked with the broader issue of freedom of speech and art. This was the case with Bakr as well:

Bakr: Yes, I have suffered because of the arts. I was persecuted because I am an artist. That's exactly what is hurting my heart. (Interview, autumn 2016)

Bakr Hasan is a professional actor and director from Iraq. Artistically he describes himself as following the steps of the French 20th century avant-garde theatre maker Antonin Artaud and his concept of the theatre of cruelty (Artaud, 1938). He defines himself as an atheist with Sunni-M uslim background. His family belonged to a religious clan, his father being an Imam, and against performing arts. When Bakr was 14 years old, his parents sent him to a faith school, where the rules were very strict. Bakr did not fit in, he tried to escape from the school, and he was physically punished because of his misbehavior. Bakr was 15 years old when he realized that he would like to be an actor and go to an art school. The imams in the faith school said that Bakr "has a devil living inside of him." Bakr's cousin was attending an art school in Baghdad and he encouraged Bakr to come and see him act in William Shakespeare's J ulius Caesar. Bakr saw the play and proclaimed: "I want to join you!" His cousin introduced Bakr to the director of the arts school. Bakr passed the entrance exam, and started his studies in secret from his family.

When Bakr was a student he participated in several performances, which criticized the political regime and Islamic religion in Iraq. Bakr's family found out about his activism, and cut their ties with him. After Bakr graduated from the art school, he was not accepted to any of the state theatres because of his activism. According to him, "they knew that I was rebellious." He made his living by selling clothes in a shop. His relative had a barber's shop, where he had a safe place for Bakr in the upstairs.

Samuel Beckett's play Waiting for Godot was crucial for Bakr. He sold everything in order to get money for the staging and performing the play. Bakr said that he "wanted to question God's existence". Waiting for Godot, as well as many other performances, resulted in the situation that Bakr and his colleagues were all under the threat to be killed because of their work, and they had to flee the country. Bakr fled to Finland in 2015. He recalled, "I saw hope in front of me. I saw light in the tunnel. I went towards the light."

Jussi: When I first met Bakr, I saw a passionate theatre practitioner who was talking about the classical 20th century Western theatre theories in a most unique way, and associating 
them with his background in Iraq and his current situation of seeking asylum in Finland. Bakr didn't seem to speak English or Finnish, and we talked with the help of interpreters. I soon realized that art was the most important thing for him. Before I started working with him he had already performed several times in Finland. The second time I met him was when he made a guest performance of his play "M ade in Baghdad" (2016) in The National Theatre. It was an impressing performance and it received an interesting response from the audience posing him questions about Iraqi theatre culture and his motives to act in Finland. I realized that Bakr made himself understood through art, but maybe not only in the way he thought he would.

Bakr recalled the asylum interview in The Finnish Immigration Service (Migri). In the interview he had described in detail his art and how he acted in the Waiting for Godot. He told us about the investigator's immediate reactions:

Bakr: The investigator said: "You can return even if there is a danger in Iraq. You can go back and behave well. Do not mock anyone, do not criticize, do not slander. You will then be safe there. Leave the theatre!" (Interview, autumn 2016)

Jussi: After interviewing Bakr I was interested to know why his application had been rejected. The moment when I read Bakr's decision on asylum changed the direction of the documentary theatre project.

In the written memo of the interview it became evident that neither the interpreter nor the interviewer recognized the play or the writer. Waiting for Godot was written as Fi Entethar Godot and Samuel Beckett became unrecognizable Sumael Bikit. Bakr's work as an actor and was defined in the memo as something that "causes chaos and just aims at shocking people" rather than as serious artistic expression and freedom of speech. In addition, the negative decision on Bakr's asylum application was justified by the argument that Bakr's artistic activities were seen as small-scale and occasional - his professional profile was not sufficiently convincing and was not regarded as belonging to the artist's identity that could not be changed to something else. When the Other Home team came to know Bakr, he had already appealed against the negative decision to Migri.

Jussi: When I saw that the Finnish government is telling Bakr to go back to Iraq and change his profession and stop expressing his ideas, I felt that something has happened to the 
concept of freedom of speech in Finland. We should make a performance about this, rather than about integration. This seemed to be OK for Bakr. Sometimes I was not sure. Would making his case public put him in a bad position either in Finland or in Iraq if he would be deported? I always talked to Bakr through an interpreter. Was there an understanding between us? Art and being an artist was a big part of the communication. Did I interpret it well enough? This made our communication in a strange way direct and indirect at the same time.

Sari: The interview left me with doubt - would it really be possible that Finnish immigration authorities would regard Bakr as someone causing chaos? Was this really what Bakr meant? We were dependent on the interpreter, who certainly was a professional, but could this be an overreaction? Jussi showed me the decision on Bakr's asylum application. It was difficult to read such an ignorant statement about arts and freedom of speech. This was clearly a turning point in the whole Other Home project. We decided with Jussi and Kati to make Bakr's and other artists' case public - the focus of Other Home needed to be changed. We wrote a letter to the editor in Helsingin Sanomat, leading Finnish newspaper. At the same time the Association of Finnish Theatres with several artist communities wrote an appeal to support Bakr and in general to change inhuman asylum policy in Finland. The Finnish broadcasting company YLE reacted to this appeal and made the news about refugee artists and inability of M igri to assess artists' risk to be persecuted in Iraq. Bakr was one of the two leading figures in the news along with an Iraqi musician Ali.

The project continued in spring 2017 with two low-threshold workshops organized in collaboration with City of Helsinki as part of integration activities for refugees and asylum seekers. One of the workshops focused on music and the other explored poetry and music as artistic expression. There were approximately 20 participants in the workshops. M ost of the workshop participants had very little previous experience in making art, and that was not expected either. Most of the participants had been in Finland for not more than two years. Some of the participants were still waiting for their asylum applications to be processed.

In autumn 2017, the dramatist Kati had finished the first draft of the manuscript of the Other Home performance. The rehearsals started, and four refugee artists were recruited to act the leading roles, Bakr being one of them, in the performance with two Finnish artists. Also the low threshold workshops continued later in the autumn. Twelve participants (ten men and two women, between 
the ages of 16 to over 60 years old) were recruited as assistants to form the chorus of the performance.

Sari: I noticed that Bakr seem to gain a lot of respect among the younger participants in the workshop. I talked with Yousef, a Syrian teenager, who said that he follows Bakr's example and asks for advice from Bakr to develop his acting.

Figure 1. Other Home performance, members of the hybrid community of artistic expression.

The stories and backgrounds of all the refugee members of the hybrid community of artistic expression represented different sides of the conflicts in their countries of origin. It was not easy to build a joint performance when there were opposing opinions about the reasons of the conflicts "back there." Both the government forces and the rebels of the Syrian civil war were represented. There were also potential tensions between the Sunni and Shia M uslims, and Kurds, Druzes, Iraqis and Iranians.

Bakr's story became a major element in the manuscript, and in the final performance it was positioned in a dialogue with other stories of the performance. In the first rehearsals Bakr told that he was a bit worried how the other participants, especially the assistants in the chorus, would receive his story about his religious family, and his difficulties in finding his own path to be an actor. After getting acquainted with the idea the whole community agreed on participating in telling of Bakr's story. It was seen as mirroring the stories of the other members of the community as well.

Jussi: It took quite a long time for me to make the final decision of employing Bakr to the core team of Other Home. I was waiting for his case to be solved to know whether he would be in Finland during the rehearsal period or not. Another issue was my perception of Bakr as a solo artist. Would he be interested to co-operate with such a complex combination of people from different cultures and language backgrounds? Would there be an understanding between me as the director of the performance and him as an actor and as one of the main "cases" of the project. How would he make himself understood in the group? When we started the rehearsals Bakr's situation was in the core of the whole performance. His case was unsettled and we wanted to point out the injustices he had experienced in the Finnish asylum system. He found his place in the community. It wasn't too difficult. When there were problems of understanding or communication, our common 
language of theatre came often to help. He showed what he wanted. He showed us what the limits of his interaction were and whether they could be challenged. In a way he remained a solo-artist throughout the process. But he was rather open to the suggestions the other members of the community made him, also to my suggestions.

Sari: I followed the rehearsals every week, and made field notes about the progress of the acts, and how meanings were negotiated among the actors with help of volunteer interpreters, who were at the same time members of the hybrid community of artistic expression. Bakr was heavily dependent on the interpreters in order to get his thoughts verbalized to Jussi and others. He explained to me that he wants to be very explicit in communicating his ideas, and limited proficiency in Finnish would not enable him doing this. He wrote his thoughts into a pink notebook that was covered with a Disney princess. It looked like Jussi and Bakr were reading each other using other semiotic resources, such as gestures and facial expressions. Spoken Arabic and Finnish were collaboratively learned and taught in the group. The script, which kept changing until the very end of the rehearsals, was a common source for commenting on other members' actions and keeping the group spirit high. Changing life situations of the refugee actors did affect the rehearsals. It was not easy to put aside the news from M igri or "back there". The role of Finnish actors and other members of the staff (sound, lightning, and props) became to support and comfort refugee artists and assistants, most of who were very young and could be their children's age.

Finally, the Administrative Court stated that the decision of M igri was made based on false argumentation. In the decision all the materials (appeals, media coverage, and factual information about artistic work) that we had forwarded to the Administrative Court via Bakr's solicitor were mentioned. The decision came just one month before the premiere, and the manuscript was adjusted accordingly.

When Bakr received notification of the positive decision, his story became known by the whole community. Every member of the group had played the scene in which his father curses him because of his career choice and thus they had placed themselves in the positions of Bakr and Bakr's father. The community had also witnessed Bakr's monologue concerning his desperate need to go back to her mother's womb, so he would not have been born in the middle of an armed conflict. Bakr also acted a comedian role as an Iraqi woman living in Finland who wished for a refugee man to marry her daughter. This role was a part of the storyline of another performer in Other Home. Yet he was a 
'Bitch-Bakr,' an asylum seeker who receives a negative decision for his asylum application, and ends up working as a prostitute. One of the most powerful scenes included in the performance is set in the Finnish Immigration Service and it depicts Bakr asylum interview.

Figure 2. Bakr and fathers.

The premiere of Other Home performance took place in November 2017 and it received a significant amount of attention in media. When the rehearsals had begun, seven of the 16 refugee performers were without a residential permit and all of them faced the risk of deportation. Supporting their communal and personal situations and processes was an integral part of the action of the hybrid community of artistic expression. By the time of the premiere three persons were still claiming for their negative decisions and living with uncertainty as a result. It was psychologically demanding for all the members of the community, because all were stakeholders in one way or another. The Other Home project received regular work counselling from the Finnish Association for M ental Health to cope with the psychological stress the changing situations caused to everyone.

Throughout this process, civic activism within the project continued, and many members of the community co-operated with Stop Deportations activists, experts in human rights issues, researchers, and artist organisations in order to support asylum applications, and provide researchbased evidence. In December 2017 ArtsEqual research initiative published a policy brief about refugee artists and international protection with us among the writers (Karttunen et al., 2017).

We interviewed Bakr once more in the end of the Other Home project. Bakr told that his thoughts and opinions about artistic expression and freedom of speech have become even stronger during the project. He also stated that without support and publicity he probably would not have received positive decision after all. During the asylum process it was too difficult for him to think about the future, and he only focused on the performances, he told. Now, after he had received a permanent residency, he is able to start writing and planning his future steps in Finland. He hopes one day to perform his plays in Iraq.

Jussi: Bakr is living in his own world as we all do. He is a very warm person. I am sure he will be walking his own paths. Will he find his place in the Finnish theatre scene? I think he will. The experience of Other Home will help him. Will he make the compromise of learning the language of his new country of residence? If so, will this change his art and thinking? 


\section{Searching for a common ground and place for hope}

Other Home was a documentary theatre project put together by the Finnish and refugee artists and artists, and produced by The Finnish National Theatre. In this chapter we have looked at the Other Home project as forming a hybrid community of artistic expression and focused on the case of the Iraqi theatre maker Bakr Hasan.

Jussi: Putting oneself to the other's position is a basic element in how the hybrid community of artistic expression works. It's how we live with each other. And it's also a theatre game: "I imagine that I am you. I imagine how you see me. We imagine that we are you. We imagine how you see us." And the other way around. Let's see where this leads us.

For Bakr Hasan the Other Home project and the hybrid community of artistic expression that it created was a place where his personal story became public and political in many ways. It was his entrance to the Finnish art world. The community consciously worked for the transition in many ways. In taking Bakr's position the other members of the community where talking to the wider audience about his case objecting the unjust policies of the Finnish migration and asylum system and speaking for the value of freedom of speech. We as members of the community made a very big effort in fighting for Bakr's rights, thus questioning the borderlines between being an artist or researcher and an activist. This specific documentary theatre project became intertwined with the reality of seeking asylum in such a way that it made Migri an agent or "actor" in the artistic process. The hybrid community of artistic expression for its part gained a critical awareness (Darder, 2015) and through its performance showed resistance against the current political regime.

Theatre artist and scholar Jules Odendahl-James (2017) writes how documentary theatre simultaneously questions and shapes the reality. It inverts the margin and the centre, and interrogates the structures of authority. This is done by giving space to lesser known and counternarrative aspects of the reality. She highlights the body-to-body experience in defining what makes documentary theatre such a complicated and dangerous art form. A sense of danger was also present in Bakr Hasan's part of Other Home. Putting oneself in his position meant for his fellow performers or spectators to feel his pain and dreams in flesh. 
A hybrid community of artistic expression is an imagined community that perpetuates a vision of its inner sameness while also being aware of the phenomena that cause its members to be different. This is part of the community's self-narrated story which makes it a kind of community shaped by differences (Morley, 2000). The hybrid community of artistic expression does not exist without an audience. And when the audience enters the performance space, there are then two imagined communities looking at each other. It is a community within the community that is challenging the very idea of a community. The borderlines of these imagined communities will not be the same after the encounter. This is the place for hope. We will give the final word to one of the members of Other Home:

Haider: I want to thank my Toinen koti [Other Home] Family! This family gave me a lot of things. I have been in a difficult situation but they're trying to make my life easy and keep hope and support me however! I wanna say I'm so proud of myself to be part of this family! And Big thanks to all my Finnish friends for supporting and coming to see us! (Facebook post, winter 2018.)

This work has been partly supported by the Academy of Finland through two research projects: ArtsEqual (grant number: 293199), and Crossing Borders - Artistic Practices in Performing and Narrating Belonging (grant number: 308520).

\section{Reference list}

Anderson, B. (1991). Imagined communities: Reflections on the origin and spread of nationalism. London, UK: Verso.

Amnesty International (2017). What's the difference between an asylum seeker and a refugee? https://www.amnesty.org.au/refugee-and-an-asylum-seeker-difference/ [accessed 17 April 2018]

Anthias, F. (2012). Transnational mobilities, migration research and intersectionality. Towards a translocal frame. Nordic Journal of M igration Research 2(2), 102-110.

Artaud, A. (1938). Le théâtre et son double. Paris: Gallimard. 
Karttunen, S., Rautiainen, P., Lehtonen, J., Teikari, A., Sandal, G., Pöyhönen, S. \& Haapakangas, E. (2017). Taiteilija turvapaikanhakijana ja kansainvälisen suojelun kohteena. Policy Brief 4.

http://www.artsequal.fi/documents/14230/0/PB vainotut taiteilijat/fbe10926-9fc1-4cbe-beaedaa10ec977d1 [accessed 16 April 2018]

Bhabha, H. (1994). The location of culture. New York, NY: Routledge.

Butler, J. \& Spivak, G.C. (2007). Who signs the nation-state? Language, politics, belonging. London, UK: Seagull Books.

Copland, F. \& Creese, A. (2015). Linguistic ethnography: Collecting, analysing and presenting data. London, UK: Sage.

Darder, A. (2015). Freire and education. New York: Routledge.

Freire, P. (1974/2013). Education for critical consciousness. New York, NY: Seabury Press.

Hall, S. (1987). 'M inimal selves.' In H. Bhabha \& L. Appignanesi (Eds.), Identity - the real me (pp. 4446). London, UK: Institute of Contemporary Arts.

Jackson, S. (2011). Social works: Performing art, supporting publics. New York: Routledge.

Kiertuenäyttämö (2018). Touring Stage. http:// www. kiertuenayttamo.fi/esitykset/toinen-koti/ [accessed 16 April 2018]

Koski, P. (2015). Challenging the Centre: Asylum Seekers Encounter Native Citizens. Nordic Theatre Studies 27 (1), 42-55.

Lehtonen, J. (2015). Elämäntunto - näyttelijä kohtaa hoitolaitosyleisön. Acta Scenica 42. Helsinki: University of the Arts, Helsinki, Theatre Academy, Finland.

Lehtonen, J. (2016). Ilmaisuyhteisön tarina. Ex-vankien ja taiteilijoiden yhteisö Vapauden kauhu projektissa. In J. Lehtonen (Ed.), Vapauden kauhu. Kirjoituksia vankilasta vapautuvien teatterista. Helsinki: The Finnish National Theatre \& ja Criminal Sanctions Agency. Publications of the Finnish National Theatre 70, 108-131. 
Morley, D. (2000). Home territories. Media, mobility and identity. London, UK: Routledge.

Odendahl-James, J. (2017). A History of U.S. documentary theatre in three stages. American theatre. http://www.americantheatre.org/2017/08/22/a-history-of-u-s-documentary-theatre-in-threestages/ [accessed 16 April 2018]

Other Home/Toinen koti project (2018) http:// www.kiertuenayttamo.fi/esitykset/toinen-koti/ [accessed 16 April 2018]

Porttiteatteri/Gate theatre (2018) https://porttiteatteri.fi/ [accessed 16 April 2018]

Pöyhönen, S., Tarnanen, M., Simpson, J. (2018). Adult migrant language education in a diversifying world, (pp. 488-503). In A. Creese \& A. Blackledge (Eds.), The Routledge Handbook of Language and Superdiversity.

Pöyhönen, S. \& Tarnanen, M. (2015). Integration policies and adult second language learning in Finland, (pp. 107-118). In J. Simpson \& A. Whiteside (Eds.), Adult Language Education and Migration. Challenging Agendas in Policy and Practice. London, UK: Routledge.

Sachs, J. (2000). The activist professional. Journal of Educational Change 1 (1), 77-94.

Touring Stage/Kiertuenäyttämö (2018). http://www.kiertuenayttamo.fi/info/briefly-in-english/ [accessed 16 April 2018]

UN High Commissioner for Refugees (UNHCR) (2006) UNHCR M aster Glossary of Terms, June 2006, Rev.1, available at: http://www.refworld.org/docid/42ce7d444.html [accessed 16 April 2018] 


\section{Bionotes (max 250 words):}

Jussi Lehtonen is artistic designer of the Finnish National Theatre's Touring Stage, where he also works as a director and an actor. The troupe takes theatre performances out on the road to places like health care institutions and prisons, and contributes community-oriented documentary theatre to the National Theatre's repertoire. Lehtonen defended his Theatre Arts PhD on actor's contact with audiences living in care facilities in 2015 at The Theatre Academy of The University of Arts, Helsinki. He is currently pursuing post-doctoral research as part of the ArtsEqual project funded by the Academy of Finland, in which he examines art as a public service and explores the potential of art to create a more equitable society. Lehtonen's writing credits include "Samassa valossa näyttelijäntyö hoitolaitoskiertueella" ("In the same light: Touring care facilities as an actor") and "Vapauden kauhu - kirjoituksia vankilasta vapautuvien teatterista" ("Terror of Freedom: Essays on theatre for released prisoners").

ORCID: 0000-0003-3131-665X

Sari Pöyhönen is professor of applied linguistics at the Centre for Applied Language Studies, University of Jyvaskyla, Finland. Her research and writing focus on language, identity and belonging, minorities and language rights, migration and asylum policies, and adult migrant language education. Through linguistic ethnography, creative inquiry and narrative approaches she is focusing on individuals interacting with others and telling their stories that are embedded with wider cultural and political contexts and social structures.

ORCID: 0000-0003-1507-7206 